\title{
Práticas judiciárias no campo criminal e a construção das verdades na persecução penal: um debate a partir de Michel Foucault
}

Legal practices in the criminal field and the construction of truths in criminal persecution: a debate grounded on Michel Foucault

Bruno Cavalcante Leitão Santos ${ }^{1}$

Pontifícia Universidade Católica do Rio Grande do Sul - Porto Alegre/RS brunoleitao.adv@hotmail.com http://lattes.cnpq.br/9699629460607799

https://orcid.org/0000-0001-7556-2348

Francisco de Assis de França Júnior ${ }^{2}$

Universidade de Coimbra/Portugal fafjunior2016@gmail.com http://lattes.cnpq.br/2739102277898461

(D) http://orcid.org/0000-0002-6958-920X

\section{Hugo Leonardo Rodrigues Santos ${ }^{\mathbf{3}}$}

Universidade Federal de Alagoas - Maceió/AL hugoleosantos@yahoo.com.br http://lattes.cnpq.br/6520668011243642 https://orcid.org/0000-0003-0139-0525

1 Doutorando (PUC/RS) e Mestre em direito pela Universidade Federal de Alagoas - UFAL; Professor no Centro Universitário CESMAC (Maceió/AL); Advogado.

2 Doutorando e Mestre em direito pela Universidade de Coimbra (PT); Professor no Centro Universitário CESMAC (Maceió/AL); Advogado.

3 Doutor em Direito pela Universidade Federal de Pernambuco - UFPE; Professor da Universidade Federal de Alagoas - UFAL e do Centro Universitário CESMAC (Maceió/AL). 
Resumo: O presente artigo tem como objetivo principal analisar criticamente práticas judiciárias emblemáticas no campo criminal e o seu papel na construção das verdades que interessam à vigente persecução penal brasileira. Importa-nos discutir, por exemplo, se a exposição de pessoas presas e a busca pela confissão são instrumentos legítimos de um sistema que se anuncia como acusatório. O recorte dessa problemática, tão importante quanto complexa, será estruturado a partir de Michel Foucault, autor cujas escavações conceituais nos permitem observar mais nitidamente as articulações realizadas pelo sistema oficial de controle rumo à manutenção de seu acentuado protagonismo no exercício do poder punitivo. As hipóteses utilizadas no desenvolvimento estão baseadas na ideia de que as midiáticas apresentações de pessoas presas e a busca pela confissão do investigado são elementos fundamentais nesse processo histórico de circularidade autoritária, mantendo-se atualmente circunstâncias absolutamente desrespeitosas de direitos e garantias constitucional e democraticamente estabelecidas.

Palavras-chave: Práticas judiciárias; Persecução Penal; Construção das verdades; Garantias constitucionais.

ABSTRACT: The main objective of this article is to critically analyze emblematic judicial practices in the criminal field and its role in the construction of the truths that are relevant to the current Brazilian criminal persecution. It is important to discuss, for example, whether the exposure of prisoners and the search for confession are legitimate instruments of a system that announces itself to be accusatory. The cut of this problematic, as important as it is complex, will be structured from Michel Foucault, author whose conceptual excavations allow us to observe more clearly the articulations carried out by the official system of control towards the maintenance of its accentuated protagonism in the exercise of punitive power. The hypotheses used in the development are based on the idea that the mediatic presentations of prisoners and the search for the confession of the investigated are fundamental elements in this historical process of authoritarian circularity, currently maintaining absolutely disrespectful conditions of rights and guarantees constitutional and democratically established.

KEYwords: Legal practices; Criminal persecution; Construction of Truths; Constitutional guarantees.

SuMÁRIO: 1. Introdução: Michel Foucault e a construção das verdades no campo criminal; 2. A verdade e as formas jurídicas; 3. Obrar mal, 
decir la verdad; 4. O papel atribuído ao investigado na persecução penal brasileira: as apresentações e a busca pela confissão como parte do processo de construção das verdades; Considerações finais; Referências.

\section{Introdução: Michel Foucault e a construção das VERDADES NO CAMPO CRIMINAL}

Tentar desvelar o que escondem as práticas já naturalizadas na dinâmica social não é um desafio simples. Para superá-lo, cumpre empreender esforços para uma educação do olhar. Quem se dispõe a encarar as complexidades que se apresentam nesse tipo de percurso deve possuir certos atributos: um apurado senso crítico, além de um certo ceticismo e uma constante inquietação que transborda o academicismo. Paul-Michel Foucault os possuía. Entretanto, ressalte-se desde já que tentar traduzir suas ideias é sempre um empreendimento perigoso, sobretudo, em linhas tão breves ${ }^{4}$. Aliás, justamente por isso, não nos restou outra alternativa, senão utilizarmo-nos com frequência de notas de rodapé, sempre indicando as fontes que podem servir para o aprofundamento de algumas das reflexões propostas.

Sua coragem e disposição para o enfrentamento de questões até então menosprezadas pelo ambiente acadêmico mais convencional nos legou uma obra que poderia ser comparada, como o próprio Michel Foucault diria ${ }^{5}$, a uma recheada caixa de ferramentas. Aulas, conferências, artigos, livros e entrevistas constituem um vasto instrumental, à inteira disposição daqueles destemidos, interessados em confrontar os sistemas sociais de controle e de punição - os quais estão sempre irrigados político-ideologicamente pelos que procuram se manter desembaraçadamente no exercício do poder, sobretudo no exercício do poder punitivo.

4 Isso porque "ele mesmo jamais expôs integralmente sua doutrina, deixou para seus comentadores essa temível tarefa”. VEYNE, Paul. Foucault - seu pensamento, sua pessoa, $2^{\mathrm{a}}$. ed. Rio de Janeiro: Civilização Brasileira, 2014. p. 17.

5 FOUCAULT, Michel. Segurança, penalidade e prisão. Rio de Janeiro: Forense Universitária, 2012. 
Percebe-se que o instrumental foucaultiano não tem nada de sublime, tendo sido moldado para o trabalho sujo, para uma espécie de escavação intelectual interessada nas filigranas, nos vestígios menos visíveis, em singularidades e em detalhes geralmente expurgados pela maioria dos pesquisadores ${ }^{6}$. Talvez por isso, se nos é permitida uma generalização - da qual Foucault era avesso -, a arqueologia seja a atividade que mais se coadune com uma tentativa de capturar o que representaria, em termos acadêmicos, o pensamento de Michel Foucault ${ }^{7}$. Suas energias estariam voltadas a "reconstituir atrás do fato toda uma rede de discursos, de poderes, de estratégias e de práticas" ${ }^{\text {. }}$.

O que se pode abstrair de cada um de seus escritos é uma espécie de sugestão para que aprofundemos ao máximo a análise das formações histórico-sociais enfocadas9. Michel Foucault não é dado a oferecer soluções prontas. Definitivamente, ele não se propôs a cumprir com esse papel, não nos impôs saídas ou fórmulas salvadoras, diante dos déficits democráticos constatados na dinâmica social ${ }^{10}$. Muito longe disso. $\mathrm{O}$ autor nos mostrou, sem recorrer a atalhos simplistas, a teia de relações extremamente fina que se estabelece entre poder, saber e (a pretensão de) verdade, estejam ou não nos aparatos estatais ${ }^{11}$. Suas investigações

6 “(...) é melhor partir do detalhe das práticas, do que se fazia e se dizia, e realizar o esforço intelectual de explicitar-lhe o discurso; é mais fecundo (porém mais difícil para historiadores e também para seus leitores) do que partir de uma ideia geral e bem conhecida”. VEYNE, Paul. Foucault - seu pensamento, sua pessoa, $2^{\mathrm{a}}$. ed. Rio de Janeiro: Civilização Brasileira, 2014. p. 21.

7 Para se ter uma ideia da importância do termo no desenvolvimento do pensamento foucaultiano, recomenda-se: FOUCAULT, Michel. A arqueologia do saber. Lisboa: Almedina, 2016. MACHADO, Roberto. Foucault, a ciência e o saber, $3^{\mathrm{a}}$ ed. Rio de Janeiro: Jorge Zahar, 2007.

8 REVEL, Judith. Michel Foucault - conceitos essenciais. São Carlos: Claraluz, 2005. p. 13.

9 VEYNE, Paul. Foucault - seu pensamento, sua pessoa, $2^{\mathrm{a}}$ ed. Rio de Janeiro: Civilização Brasileira, 2014. p. 23.

10 Nesse sentido, afirmou: "não quero de jeito nenhum desempenhar o papel de quem prescreve soluções”. FOUCAULT, Michel. La inquietud por la verdad escritos sobre la sexualidad y el sujeto. Buenos Aires: Siglo Veintiuno, 2015. p. 88, em tradução livre.

11 “(...) as relações de poder são as que os aparatos do Estado exercem sobre os indivíduos, mas assim mesmo a que o pai de família exerce sobre sua mulher e filhos, o poder exercido pelo médico, o poder exercido pelo notável, o 
estão quase sempre demarcadas pela fragmentariedade, repetitividade e descontinuidade ${ }^{12}$.

Nesse contexto, como já deixamos antever, decifrar o pensamento foucaultiano é providência que exige uma cuidadosa observância do maior número possível de suas reflexões, obrigando-nos, portanto, a transitar com alguma desenvoltura por praticamente todas as suas fases. ${ }^{13}$ A leitura parcial, quando muito, haverá de nos permitir uma análise relativamente segura de um específico escrito, de um momento de sua vida intelectual, mas não do todo de seu percurso acadêmico, de seu complexo pensamento.

Os dedicados ao estudo criminológico, por exemplo, não raramente, limitam-se a utilizar as reflexões encontradas em Vigiar e punir, ${ }^{14}$ sobretudo aqui no Brasil, onde o autor tem recebido um tratamento quase acrítico e às vezes até reverencial. ${ }^{15}$ É comum nos preocuparmos

poder que o proprietário exerce em sua fábrica sobre seus operários”. FOUCAULT, Michel. El poder, una bestia magnífica - sobre el poder, la prisión y la vida. Buenos Aires: Siglo Veintiuno, 2014. p. 42, em tradução livre. FOUCAULT, Michel. Op. Cit. p. 12.

É possível traçar um esboço de divisão de sua obra. Seguindo o método de classificação por fases, bastante difundido entre os que se dedicam a estuda -lo, três delas merecem destaque: a arqueológica; a genealógica; e a ética (ou estilística da existência). Na primeira delas, focada, grosso modo, no estudo do discurso, o pensador francês escreveu as seguintes obras: História da loucura (1961), Nascimento da clínica (1963), As palavras e as coisas (1966) e a Arqueologia do saber (1969). Em sua segunda fase, dedicada mais propriamente ao estudo dos poderes disciplinares decorrentes dos discursos, surgiram: $\mathrm{Vi}$ giar e punir (1975) e a História da sexualidade I: vontade de saber (1976). Na terceira, com foco na análise de como a pessoa se autogoverna, provavelmente sua fase menos estudada pelos interessados em discutir seu pensamento, tivemos: História da sexualidade II: o uso dos prazeres (1984) e a História da sexualidade III: o cuidado de si (1984).

O mesmo pode ser dito quanto aos psicólogos, que por vezes se atêm tão somente à História da loucura.

Para uma leitura crítica do uso de Michel Foucault em terrae brasilis, trabalhando, aliás, com a hipótese de que no Brasil não teríamos uma sociedade disciplinar nos moldes daquela estudada pelo autor francês, recomenda-se: OLIVEIRA, Luciano. Relendo Vigiar e Punir. Revista Olhares Plurais - revista eletrônica multidisciplinar, vol. 1, n. 4, 2016, p. 6-30. Disponível em: <http:// revista.seune.edu.br/ index.php/op>. Acesso em 20.03.2017. E ainda: OLIVEIRA, Luciano. O aquário e o samurai: uma leitura de Michel Foucault. Rio de Janeiro: Lumen Juris, 2017. 
em traduzir as interações do sistema de controle e de punição sem nos aprofundarmos nas questões pré-conceituais, trabalhadas em sua fase arqueológica. É, pois, preciso percebermos seus rastros, as chaves interpretativas espalhadas no desenvolvimento de seu trabalho ${ }^{16}$, os deslocamentos conceituais, as constantes rupturas que ele provoca, as descontinuidades coerentes de seu pensamento ${ }^{17}$. Pode-se considera-lo, em linhas gerais, uma espécie de antimetodologista ${ }^{18}$.

As considerações feitas até aqui se justificam pela preocupação em tentar demonstrar que não temos a menor pretensão de analisar as práticas judiciárias no campo criminal e a construção das verdades com base no todo do pensamento de Michel Foucault, tampouco de construir reflexões acessando isoladamente um de seus trabalhos. O recorte proposto neste artigo está ancorado em reflexões que foram transmitidas ao público em períodos que perpassam por, pelo menos, duas de suas fases (a arqueológica e a genealógica). Apesar de todas as contingências efetuadas, essa proposta parece-nos interessante, para a compreensão das idiossincrasias do sistema criminal.

16 Foucault cunhou um vocabulário técnico próprio, como, por exemplo, suas ideias de episteme e de discurso, que aqui, por fugir de nossos propósitos com o presente estudo, não iremos aprofundar.

17 "As rupturas - ocorreram -, as dificuldades - não faltaram -, os arrependimentos - tiveram seu papel -, tudo conspira para no final dar uma impressão de uma coerência organizadora”. ERIBON, Didier. Michel Foucault. São Paulo: Companhia das Letras, 1990. p. 211.

18 Não no sentido de que ele não tivesse um de método de trabalho, mas no sentido de que ele não seguia os métodos (uniformes) tradicionalmente dispostos àquela época. Em $A$ arqueologia do saber, por exemplo, livro escrito "para se livrar da marca do "estruturalismo", Foucault dedica-se a explicação do método que utilizava até então. ERIBON, Didier. Michel Foucault. São Paulo: Companhia das Letras, 1990. p. 173. Não à toa o referido livro tem sido, até hoje, apontado como fundamental para entender seu itinerário acadêmico até ali, embora também explique que o mesmo não se trata de um livro sobre metodologia. Foucault alega que não teria um método que se aplicaria da mesma forma a domínios diferentes. Diz ele a respeito: "sou, como se queira, um empirista cego, o que significa que estou na pior das situações. Não tenho uma teoria geral e não tenho tampouco um instrumento seguro". FOUCAULT, Michel. El poder, una bestia magnífica - sobre el poder, la prisión y la vida. Trad. Horacio Pons. Buenos Aires: Siglo Veintiuno, 2014. p. 73-74, em livre tradução. 
Nesse sentido, as primeiras reflexões que, à partida, servirão para nos embasar na construção deste trabalho, encontram-se no livro $A$ verdade e as formas jurídicas ${ }^{19}$, resultado de cinco conferências que o autor proferiu na Pontifícia Universidade Católica do Rio de Janeiro, no Brasil; as demais encontram-se em Obrar mal, decir la verdad - la función de la confesión en la justicia ${ }^{20}$, resultado de seis conferências realizadas na escola de criminologia da Universidade Católica de Louvain, na Bélgica. Perpassaremos as ideias centrais, refletindo com o autor, e não propriamente como ele. Ademais, nossas ponderações, embora partam dele, não se limitarão ao pensamento foucaultiano.

Por fim, nosso principal objetivo é o de tentar desvelar, ainda que sucintamente, o que estaria por trás dos discursos utilizados para sustentar a dinâmica autoritária (quase sempre disfarçada) de funcionamento do sistema criminal brasileiro, sobretudo, no âmbito da participação do investigado (eis aqui o problema fulcral). A investigação criminal, por sua vez, especialmente quando envolta pela comoção social, deflagra uma busca quase que desenfreada pelo estabelecimento de uma verdade, uma pressão quase que incontida pela apresentação de culpados, pela exposição de suas confissões e arrependimentos e, é claro, pelo pronto reestabelecimento da ordem discursiva violada pelo suposto delinquente.

Das inúmeras práticas judiciárias no campo criminal, interessamnos aqui, em especial, as já popularizadas apresentações à imprensa, bem como as confissões, patrocinadas com entusiasmo e pompa por agentes estatais. A tríade prisão/exibição/confissão é sintomática na investigação e na dinâmica social brasileira. O ritual de expor o inimigo capturado e fazê-lo reconhecer seu erro publicamente, atraindo a atenção da sociedade sedenta por essas humilhações -, constitui-se numa mensagem poderosa (aos "filhos") passada pelo Estado ("pai") de que tudo está sob controle ${ }^{21}$.

19 FOUCAULT, Michel. A verdade e as formas jurídicas. Rio de Janeiro: NAU, 2002.

20 FOUCAULT, Michel. Obrar mal, decir la verdade: la función de la confesión en la justicia. Buenos Aires: Siglo Veintiuno, 2014.

21 Sobre a ideia de um pai punitivo, ver: FREUD, Sigmund. Totem e tabu. Obras completas, v. 11. São Paulo: Companhia das letras, 2012. Sobre a relação entre esse conceito psicanalítico e o sistema penal, ver: BATISTA, Nilo. A lei como pai. Passagens, v. 2, n. 3. Rio de Janeiro, 2010, p. 20-38. 
Nas palavras do próprio Foucault ${ }^{22}$, um tipo de comportamento que se constitui numa insistente e inócua tagarelice criminológica.

É no contexto acima descrito e sem qualquer pretensão de esgotar o assunto, que nos imiscuiremos junto à obra de Michel Foucault. Antes, porém, um último registro merece ser feito. As lições do autor enfocado foram construídas, como é óbvio, com suporte na realidade francesa de sua época, a realidade em que ele vivia, apesar de suas eventuais incursões por outros países, em especial os do continente europeu. Desse modo, como bem alertou Luciano Oliveira ${ }^{23}$, nosso esforço também estará voltado para, sempre que nos for possível, tentar conciliar reflexões amparadas nos padrões franceses com a realidade marginal historicamente vivenciada pelos brasileiros. Eis os desafios dispostos à frente.

\section{A VERDADE E AS FORMAS JURÍDICAS}

As conferências apresentadas por Michel Foucault no Brasil, ${ }^{24}$ ocorreram no auge do golpe militar, mais propriamente em maio de

22 FOUCAULT, Michel. Segurança, penalidade e prisão. Rio de Janeiro: Forense Universitária, 2012. p. 283.

${ }^{23}$ OLIVEIRA, Luciano. Relendo Vigiar e Punir. Revista Olhares Plurais - revista eletrônica multidisciplinar, vol. 1, n. 4, 2016, p. 6-30. Disponível em: <http:// revista.seune.edu.br/index.php/op>. Acesso em 20.03.2017.

${ }^{24}$ Foucault já havia proferido uma série de conferências em São Paulo, em 1965, a convite de Gérard Lebrun, seu antigo aluno, a quem mostrou e pediu que opinasse sobre o manuscrito que se tornaria As palavras e as coisas. ERIBON, Didier. Michel Foucault. São Paulo: Companhia das Letras, 1990. p. 148. Em 1967 ele revela sua admiração aos estudantes brasileiros: "Probablemente sólo en Brasil y Túnez encontre entre los estudiantes tanta seriedad y tanta pasión, pasiones tan serias, $\mathrm{y}$ - lo que más me encanta de todo - la avidez absoluta por saber". FOUCAULT, Michel. ¿Qué es usted, professor Foucault? sobre la arqueología y su método. Trad. Horacio Pons. Buenos Aires: Siglo Veintiuno, 2014. p. 80. Foucault volta novamente ao Brasil em 1975 (onde havia estado também em 1974), quando em 25 de outubro, presencia toda a repercussão negativa da morte do jornalista Vladimir Herzog nas dependências do DOI-Codi em São Paulo. Extremamente irritado, Foucault interrompe a série de conferências que tinha programado e deixa o país, não sem antes registrar publicamente "que se recusa a ensinar num país onde não existe liberdade". Apesar disso, retorna em 1976, quando vai a Salvador, Recife e Belém. ERIBON, Didier. Michel Foucault. São Paulo: Companhia das Letras, 
1973. Suas realizações foram viabilizadas pelo departamento de Letras da Pontifícia Universidade Católica do Rio de Janeiro - o qual, mesmo diante das circunstâncias autoritárias da época, consistia em um espaço de resistência liberal ${ }^{25}$.

Para se compreender as práticas judiciárias no campo criminal e a construção das verdades a elas vinculadas seria preciso atentar, em primeiro lugar, para "a natureza das lutas que, numa sociedade, se desenrolam em torno do poder" ${ }^{26}$. Paredes meias com os postulados abolicionistas, contrapondo criticamente os ideais hobbesianos, Foucault destacava que "o crescimento do poder faz os homens entrarem no sistema dos signos, das marcas, e o aumento de poder está essencialmente destinado a instaurar nas relações entre os homens a marca visível [do] poder [de um deles]"27. Avançando para a problemática da punição, estágio mais acentuado das relações de poder, questiona-se: por que então a forma-prisão ganhou relevo entre as práticas judiciárias? Essa, aliás, segundo ele, seria uma indagação negligenciada historicamente pelos pesquisadores ${ }^{28}$.

1990. p. 288-289. Para mais informações sobre a presença do autor francês no Brasil, ver: MACHADO, Roberto. Impressões de Michel Foucault. São Paulo: N-1, 2017.

25 Alguns meses antes da visita ao Brasil, Foucault havia concluído seu concorrido curso sobre a sociedade punitiva, no anfiteatro do Collége de France. Entre janeiro e março daquele ano de 1973, todas as quartas-feiras, ele esteve interessado na elaboração de críticas das noções de exclusão e de transgressão atreladas a determinadas instituições, como, por exemplo, os hospitais psiquiátricos. Sua hipótese de partida seria a de que existiriam sociedades (ou penalidades) de exclusão, indenização, marcação ou reclusão. Nesse contexto, as táticas utilizadas para reagir contra os que se dispunham a contestar aqueles que detinham o poder, além do próprio sistema penal, foram os objetos de sua escavação durante o curso. Veja-se: FOUCAULT, Michel. A sociedade punitiva. São Paulo: Martins Fontes, 2015.

${ }^{26}$ FOUCAULT, Michel. A sociedade punitiva. São Paulo: Martins Fontes, 2015. p. 13.

27 FOUCAULT, Michel. Oo. Cit.. p. 26.

28 Foucault, Michel. Segurança, penalidade e prisão. Rio de Janeiro: Forense Universitária, 2012. p. 285-286. "Faz-se a história do direito, a história da economia, mas raramente se fala da história da justiça, da prática judiciária, do que foi de fato um sistema penal, do que foram os sistemas de repressão". ERIBON, Didier. Michel Foucault. São Paulo: Companhia das Letras, 1990. p. 228. 
Tinha-se uma preferência, portanto, pela busca dos fundamentos abstratos do direito de punir, como se se apresentasse como mais urgente dotá-lo de alguma legitimidade/racionalidade ${ }^{29}$. Detenhamo-nos um instante nesse ponto. A racionalização das práticas punitivas parecia ter por meta a ofuscação da violência que lhe é intrínseca. Michel Foucault contrapunha-se a ideia de que isso seria possível. Nesse sentido, criticou o sistema de controle e de punição, essa forma institucionalizada de violência, afirmando o seguinte:

Na violência, o mais perigoso é a sua racionalidade. Certo, a violência em si mesma é terrível. Mas a violência encontra seu ancoradouro mais profundo e sua forma de permanência na forma de racionalidade que nós utilizamos. Se afirmou que se vivêssemos em um mundo racional, poderíamos nos desfazer da violência. Isso é completamente falso. Entre a violência e a racionalidade não há incompatibilidade. Meu problema não é condenar a razão, mas sim determinar a natureza dessa racionalidade que é compatível com a violência. Não é a razão em geral que eu combato. Não se poderia combater a razão ${ }^{30}$.

Foucault utiliza a filosofia de Nietzsche para iniciar suas reflexões junto ao público brasileiro, o que, dentre outras pistas, já nos permite prenunciar sua fase genealógica, momento em que ele passa a dar mais ênfase à análise crítica do saber-poder disciplinar. Em sua conferência inaugural, o autor martela que "práticas sociais podem chegar a engendrar domínios de saber que não somente fazem aparecer novos objetos, novos conceitos, novas técnicas, mas também fazem nascer formas totalmente novas de sujeitos e de sujeitos de conhecimento" ${ }^{31}$. É nesse interregno que se acentua a sua preocupação com as conexões entre o discurso e as práticas. Escolas, fábricas, hospitais, quarteis e, especialmente, o sistema

29 Veja-se a crítica feita por Foucault ao "humanismo" propagado com pompa por Cesare Beccaria e seus seguidores: FOUCAULT, Michel. Vigiar e punir: história da violência nas prisões. Petrópolis: Vozes, 2005.

30 FOUCAULT, Michel. Dits et écrits, v. III. Paris: Gallimard, 1994, p. 803, em tradução livre.

31 FOUCAULT, Michel. A verdade e as formas jurídicas. Rio de Janeiro: NAU, 2002. p. 18. 
de punição, eram seus principais objetos de estudo, em um esforço para desvelar as influências presentes na maneira de pensarmos hoje as ditas formas jurídicas. Segundo Foucault, as práticas penais serviriam para a definição de algumas dessas formas ${ }^{32}$, como o inquérito, por exemplo, cuja dinâmica foi analisada pelo autor francês.

Para possibilitar o acesso ao conhecimento - produto da invenção do homem e que, portanto, "não está em absoluto inscrito na natureza humana" 33 -, seria preciso nos aproximarmos da esfera do político, para tentarmos "compreender quais são as relações de luta e de poder" ${ }^{4}$. Sempre amparado em Nietzsche, Foucault ${ }^{35}$ dirá que "o conhecimento é sempre uma certa relação estratégica em que o homem se encontra”, nele haverá sempre "alguma coisa que é da ordem do duelo e que faz com que ele seja sempre singular”. É nesse contexto que o autor insere no debate uma perspectiva marxista da ideologia. Demonstrando sua discordância com o que chamou de marxismo acadêmico, Foucault ${ }^{36}$ vai apontar que, ao invés de as condições políticas e econômicas se constituírem num véu ou obstáculo que comprometem a relação do sujeito com a verdade, seriam elas, na realidade, "aquilo através do que se formam os sujeitos do conhecimento e, por conseguinte, as relações de verdade”.

Mas, por qual motivo se deveria partir da observação das práticas judiciárias, nessa análise crítica? Exatamente, porque teriam sido tais práticas o nascedouro de modelos de verdades que ainda hoje circulam em nosso meio - impondo-se, portanto, em diversos setores da sociedade, inclusive nos apontados como científicos. É na tragédia grega, mais propriamente no infortúnio de Édipo ${ }^{37}$, que Foucault ${ }^{38}$ vai buscar subsídio para tentar explicar a relação entre poder e saber, entre o poder político e o conhecimento, e daí chegar a apontar que, coletivamente, "há realmente

\footnotetext{
32 FOUCAULT, Michel. Op. Cit. p. 21.

33 FOUCAULT, Michel. Op. Cit. p. 25.

34 FOUCAULT, Michel. Op. Cit. p. 31.

35 FOUCAULT, Michel. Op. Cit. p. 33.

36 FOUCAULT, Michel. Op. Cit. p. 34.

37 SÓFOCLES. Édipo-Rei. São Paulo: Perspectiva, 2001.

38 FOUCAULT, Michel. A verdade e as formas jurídicas. Rio de Janeiro: NAU, 2002. p. 39.
} 
um complexo de Édipo na nossa civilização”. As consequências do triângulo edipiano (pai-mãe-filho) teriam sido "o primeiro testemunho que temos das práticas judiciárias gregas”. Os envolvidos no episódio, aduz nosso autor, empreenderam uma pesquisa que lhes permitiu - ao ignorarem uma certa verdade, um certo procedimento pré-estabelecido - "descobrir uma verdade que coloca em questão a própria soberania do soberano”.

As peculiaridades da narrativa de Sófocles acabaram por auxiliar na sedimentação da ideia de que "a verdade nunca pertence ao poder político" e de que "o poder político é cego" a esse respeito. Saber e poder político não se confundiriam. Coube a Nietzsche demolir esse mito e mostrar que "por trás de todo saber, de todo conhecimento, o que está em jogo é uma luta pelo poder", o que o leva a concluir que "o poder político não está ausente do saber, ele é tramado com o saber". ${ }^{39}$ Nesse sentido, o inquérito, uma vez formalizada e estatizada a justiça penal, seria uma forma política, um modo de gestão, um instrumento para o exercício do poder. Destinado a dizer a verdade, é ele, portanto, uma forma de saber-poder. ${ }^{40}$ Todo esse cenário de efervescência política, especialmente depois das contribuições teóricas de Beccaria, de Brissot e, sobretudo, de Bentham - e o resultado dessas ideias nas práticas punitivas engendradas naquela época - é o que vai nos permitir identificar a formação de uma sociedade dita disciplinar ${ }^{41}$.

O empoderamento estatal nas questões do controle social não se manteve estanque nos estabelecimentos prisionais, muito pelo contrário, desaguou numa sociedade de vigilância, ou seja, "uma forma de arquitetura que permite um tipo de poder do espírito sobre o espírito; uma espécie de instituição que deve valer para escolas, hospitais, prisões, casas de correção, hospícios, fábricas etc" ${ }^{2}$. Eis o impacto do panoptismo proposto por Jeremy Bentham ${ }^{43}$, a quem Foucault atribui mais importância social do que a Kant ou a Hegel. O Panopticon "é uma forma de poder que repousa

39 FOUCAULT, Michel. A verdade e as formas jurídicas. Rio de Janeiro: NAU, 2002. p. 56.

$40 \quad$ FOUCAULT, Michel. Op. Cit. p. 79.

41 FOUCAULT, Michel. Op. Cit. p. 81 ss.

42 FOUCAULT, Michel. Op Cit. p. 88.

43 BENTHAM, Jeremy. O panóptico. Belo Horizonte: Autêntica, 2000. 
não mais sobre um inquérito, mas sobre algo totalmente diferente" ${ }^{44}$. $\mathrm{O}$ inquérito, por intermédio de práticas judiciárias, reatualizava um acontecimento, o panoptismo permitia a vigilância permanente, "um saber que tem agora por característica não mais determinar se alguma coisa se passou ou não, mas determinar se um indivíduo se conduz ou não como deve, conforme ou não à regra, se progride ou não etc." ${ }^{45}$.

É a partir desse caldo cultural que a prisão vai se firmar como o dispositivo preferido dos agentes estatais responsáveis pela manutenção da ordem. O crescimento econômico e a necessidade de se proteger a produção também fomentaram esse processo. As noções de periculosidade, de necessidade de vigilância, de correção, de ressocialização, de normalização, de controle, vão ganhar proeminência justamente nesse período (meados do séc. XVIII e início do séc. XIX) - impactando as rotinas do sistema prisional, além de diversas outras instituições. Formalizou-se socialmente uma rede de sequestros voltada principalmente ao controle absoluto dos corpos. O objeto de interesse precípuo dos mecanismos de controle não é propriamente o que se faz, mas sim, aquilo o que se poderá fazer ${ }^{46}$. A prisão se impõe, dirá Foucault ${ }^{47}$, "porque era, no fundo, apenas a forma concentrada, exemplar, simbólica de todas estas instituições de sequestro criadas no século XIX".

Com um ideário disciplinar tão difundido e reverberado, constituiu-se a prisão numa expressão de um consenso social, uma instituição da qual não se poderia abrir mão, para onde iriam apenas aqueles que cometeram uma falta, que violaram a ordem ${ }^{48}$. Sua existência, portanto, não é apenas simbólica, mas útil e funcional aos interesses dos governantes. Uma vez selecionado, sob uma perspectiva prática (tanto do senso comum quanto de profissionais da área jurídica), é o sujeito (melhor, o inimigo) quem deve envidar esforços para mostrar que não a merece -

44 FOUCAULT, Michel. A verdade e as formas jurídicas. Rio de Janeiro: NAU, 2002. p. 88.

45 FOUCAULT, Michel. Op Cit. p. 89.

46 FOUCAULT, Michel. A verdade e as formas jurídicas. Rio de Janeiro: NAU, 2002. p. 104 ss.

47 FOUCAULT, Michel. Op Cit. p. 120-121.

48 FOUCAULT, Michel. Op Cit. p. 121. 
invertendo-se, assim, a ideia de um processo democrático, segundo o qual deveria ser presumida a inocência dos acusados ${ }^{49}$. Essa presunção, aliás, não é consentânea - ao menos não integralmente - da cultura do controle, ao contrário, é potencialmente nociva à irrigação do sistema tal como historicamente vem funcionando.

\section{Obrar mal, decir la verdad}

O convite para ministrar um curso na escola de criminologia da Universidade Católica de Louvain, na Bélgica, em 1981, mesmo com toda experiência que já acumulava então, parece ter sido encarado como um interessante desafio por Michel Foucault. Tanto que, em mais de uma oportunidade, no decorrer dos encontros, solicitou que não lhe perguntassem se era um historiador ou um filósofo, e fez questão de frisar: "não venho como jurista" ${ }^{50}$. Era, muito provavelmente, a primeira vez que o pensador francês se deparava com uma plateia constituída majoritariamente por juristas e, principalmente, por criminólogos - os quais estavam todos, naquela oportunidade, envolvidos nos debates a respeito da reforma do Código Penal belga.

A realização do evento partiu de Françoise Tulkens. Partidária da perspectiva abolicionista, a professora de direito belga demonstrava insatisfação pelos rumos que haviam sido tomados pela Comissão de Reforma do Código Penal, especialmente, quanto à ideia de perigosidade $e^{51}$. Foi, portanto, nesse contexto de certa tensão discursiva que as conferências foram realizadas. Michel Foucault parecia estar ali para servir

49 Tanto que, aqui no Brasil, recentemente, o próprio Supremo Tribunal Federal já a reconhece como mitigada. Nesse sentido, vejam-se as manifestações dos Ministros do Supremo Tribunal Federal no julgamento do HC 126.292, originário do Estado de São Paulo, permitindo o cumprimento de sentença penal antes do trânsito em julgado.

50 FOUCAULT, Michel. Obrar mal, decir la verdade: la función de la confesión en la justicia. Buenos Aires: Siglo Veintiuno, 2014. p. 31. Algumas páginas adiante ele repisa: "[...] tendo em conta que não sou um jurista, nem sequer um historiador do direito", p. 39, traduzido livremente. Depois volta a insistir: "ao não ser jurista nem historiador do direito, não queria que esperassem de mim uma técnica que não sou capaz de entregar-lhes”, p. 69, em tradução livre.

51 FOUCAULT, Michel. Op Cit. p. 11. 
como um contraponto aos postulados da defesa social acolhidos pelos juristas que dominavam os debates, no processo de reforma da legislação penal local. A força de seus argumentos, o vigor de suas inquietações e a maneira desconcertante com que apresentava suas reflexões seriam o combustível necessário para fortalecer a atuação do grupo minoritário de criminológos críticos que estavam diretamente envolvidos nos debates. Todos os seus esforços acadêmicos, naquela oportunidade, voltaramse para a compreensão histórica da função da confissão no processo de investigação criminal, embora tenha sido ressaltada também, ainda que en passant, a importância da confissão em processos de natureza cível $^{52}$. Não seria a primeira vez que destacaria a confissão como objeto de reflexões, mas, pode-se afirmar que, em Louvain, o tema recebeu um tratamento privilegiado.

Ao abordar conceitualmente a confissão, na conferência inaugural, Foucault inicia afirmando que, de maneira geral, o confessor ao resolver falar afirma algo sobre si mesmo, sobre o que ele mesmo é. Mas não seria uma mera declaração. Quem assim procede, admitindo um crime (uma espécie de falta ou desvio), compromete-se de alguma forma a ser o seu autor, aceitando sua responsabilidade, sujeitando-se, obrigando-se, portanto, a ser o que disse ser. ${ }^{53}$

Não poderia faltar à análise uma perspectiva que a conectasse com um de seus principais objetos de estudo: as relações de poder. Assim, a confissão serviria para suscitar ou reforçar uma relação de poder que se exerce sobre aquele que confessa. Por isso, arremata Foucault, não há confissão que não seja custosa ${ }^{54}$. Com o passar dos tempos, a confissão acabaria se consolidando como uma espécie de discurso da verdade, uma complexa peça processual, cujo ato seria tecnicamente o que ele acaba denominando por veridiçãa ${ }^{55}$. Tal análise empreendida por Foucault, uma

52 FOUCAULT, Michel. Op Cit. p. 39. Foucault também já havia ressaltado a importância da confissão para outras áreas do conhecimento, como a medicina e a psiquiatria, p. 28.

53 FOUCAULT, Michel. Op Cit. p. 24-26.

54 FOUCAULT, Michel. Obrar mal, decir la verdade: la función de la confesión en la justicia. Buenos Aires: Siglo Veintiuno, 2014. p. 26.

55 Traduzido livremente para português de veridicción (dizer a verdade). FOUCAULT, Michel. Op Cit. p. 29. Com a expressão, Foucault recorre claramente 
vez observada a dispersão social dos regimes de veridição, é uma forma de se contrapor à uniformização técnica do mundo moderno influenciada pelo positivismo comtiano ${ }^{56}$. Vê-se claramente sua inquietação frente ao estabelecimento de fórmulas de universalização ou normalização.

O leitor já habituado com a obra de Foucault não deixará passar despercebido o enorme interesse de Foucault pela antiguidade ${ }^{57}$, muito especialmente, pela literatura grega. Em seus livros, aulas, conferências ou entrevistas, frequentemente nos deparamos com análises que estão especialmente voltadas aos textos clássicos da Grécia antiga. Isso também é notado nas conferências realizadas em Louvain. Por exemplo, é de Homero que ele se vale inicialmente, para uma análise mais detida do tema proposto. Logo no momento seguinte, vemos o autor envolto, uma vez mais, com a tragédia de Édipo, a quem Foucault atribuirá a iniciativa de colocar em marcha uma série de investigações que proporcionarão ao desafortunado personagem encontrar a temível verdade ${ }^{58}$.

Aliás, Édipo-Rei, de Sófocles, parece ter sido um de seus textos antigos preferidos, vez que aquela oportunidade seria a milionésima vez que refletiria sobre texto, segundo o próprio autor reconhece. Mais ainda, o testemunho oferecido por Paul Veyne ${ }^{59}$ parece não nos deixar dúvidas a respeito de sua preferência. Numa manhã, em seu escritório, Veyne havia sido interpelado da seguinte forma por Foucault: "Ouça, Veyne, você não acha que existem coisas em literatura que estão acima de todo o resto?

a um jogo de palavras com a ideia de jurisdição (dizer o que é justo). "a atividade de dizer a verdade e a atividade de dizer o justo, a atividade de veridição e a atividade de jurisdição", p. 39, em tradução livre. mente a busca de uma ética pessoal a uma moral como obediência a um sistema de regras. Se me interessei pela Antiguidade foi porque, por toda uma série de razões, a ideia de uma moral como obediência a um código de regras está, agora, desaparecendo, já desapareceu. E a essa ausência de moral responde, deve responder, uma busca que é a de uma estética da existência". FOUCAULT, Michel Apud VEYNE, Paul. Foucault: seu pensamento, sua pessoa, $2^{a}$ ed. Rio de Janeiro: Civilização Brasileira, 2014. p. 219-220.

FOUCAULT, Michel. Obrar mal, decir la verdade: la función de la confesión en la justicia. Buenos Aires: Siglo Veintiuno, 2014. p. 88.

VEYNE, Paul. Foucault: seu pensamento, sua pessoa, $2^{\text {a }}$ ed. Rio de Janeiro: Civilização Brasileira, 2014. p. 251. 
Para mim, a fala de Édipo cego, no fim de Édipo rei...”. Veyne aduz que o amistoso invasor, com os olhos arregalados e o livro aberto nas mãos, não concluiu a frase - agora dizemos nós -, extasiado pela leitura.

Para Foucault, Sófocles havia nos proporcionado a primeira representação dramática daquela nova prática judicial, daquela ideia de veridição, que acabou fazendo da confissão um elemento essencial do sistema judicial ${ }^{60}$. Apesar de sua influência a posteriori junto ao Direito, não se pode atribuir a gênese dessa obrigação de dizer a verdade ao cristianismo ${ }^{61}$. Não obstante, não há dúvidas de que a tradição cristã fez reverberar tal ideia ao apelo junto ao sacramento da penitência, num ritual que impõe a confissão dos pecados ${ }^{62}$. É, portanto, necessário falar de si. Entretanto, para isso, é preciso realizar um autoexame, passar em revista as faltas (os pecados), sujeitar-se ao outro, submeter-se, devotar-lhe alguma obediência. Essa confissão de boca constitui um dos elementos essenciais do ritual penitencial ${ }^{63}$.

Sabendo estar diante de um público constituído especialmente de criminólogos, em sua última conferência, Foucault falou de maneira mais detida e interessada sobre a aparição do criminoso confessante no sistema de justiça criminal e a importância da prova, que se constitui a partir daí. Abordou, após destacar o intenso processo de investigação inquisitorial e a utilização da tortura, o surgimento do sistema processual dito acusatório, para ele, centrado no enfrentamento entre dois adversários e dois interlocutores ${ }^{64}$. Com a chegada da modernidade, racionalizadora do sistema de punição ${ }^{65}$, a

60 FOUCAULT, Michel. Obrar mal, decir la verdade: la función de la confesión en la justicia. Buenos Aires: Siglo Veintiuno, 2014. p. 93.

61 FOUCAULT, Michel. Op Cit. p. 107. "O cristianismo, se não inventou, introduziu ao menos um procedimento de confissão totalmente singular na história das civilizações, coação que perdurou ao largo de séculos e séculos”. FOUCAULT, Michel. El poder, una bestia magnífica: sobre el poder, la prisión y la vida. Buenos Aires: Siglo Veintiuno, 2014. p. 82, em tradução livre.

62 FOUCAULT, Michel. Op Cit. p. 119. Foucault também atribui aos "meios religiosos” o nascimento da reclusão punitiva. FOUCAULT, Michel. A sociedade punitiva. São Paulo: Martins Fontes, 2015. p. 80.

63 FOUCAULT, Michel. Op Cit. p. 204.

64 FOUCAULT, Michel. Op Cit. p. 220.

65 Veja-se a crítica de Foucault a respeito dessa ideia de racionalização e humanização do sistema de punição, movimento cuja deflagração na história é 
confissão se converte em um evento de extrema importância, vez que ela se prestará a reconhecer a legitimidade do castigo que deverá ser imposto ao criminoso confessante. A confissão, diz-nos Foucault, nesse aspecto, será a reinstauração do implícito pacto social, sua rememoração, sendo tal espécie de prova, não à toa - mesmo atualmente - uma das mais buscadas numa investigação criminal $^{66}$.

Nesse sentido, a confissão permite a quem julga exercer sua soberania sem grandes embaraços, sem o inconveniente das incertezas, e, portanto, sem constrangimentos diante daquilo que se apresenta como uma verdade. Justo por isso, ela acabou se transformando em necessidade fundamental do sistema punitivo. Assim, é demasiado importante que o investigado confesse, que se submeta, de bom grado, às consequências previamente formuladas por seus atos, que se disponha a saciar esse apetite pela verdade e por uma legitimação - pois, somente assim, o sistema punitivo poderia funcionar plenamente ${ }^{67}$. Com efeito, se nem o destinatário da investigação contesta a imputação que lhe é feita, por que o faria a sociedade?

\section{O papel atribuído ao inVestigado na PERSECução Penal BRASILEIRA: AS APRESENTAÇÕES E A BUSCA PELA CONFISSÃO COMO PARTE DO PROCESSO DE CONSTRUÇÃO DAS VERDADES}

É a partir do século XVI que se constata mais nitidamente a estruturação daquelas que podem ser consideradas as teorias políticas mais bem embasadas da história humana. Nesse contexto, Nicolau Maquiavel é, sem dúvidas, um dos principais artífices dessa transição para uma razão de Estado. Com ele, popularizou-se a ideia de que os fins justificam os meios. ${ }^{68}$

geralmente atribuída a Beccaria com o seu Dos delitos e das penas (1764), em: FOUCAULT, Michel. Vigiar e punir: história da violência nas prisões. Petrópolis: Vozes, 2005.

66 FOUCAULT, Michel. Obrar mal, decir la verdade: la función de la confesión en la justicia. Buenos Aires: Siglo Veintiuno, 2014. p. 225-226.

67 FOUCAULT, Michel. Op Cit. p. 227.

${ }_{68}$ MAQUIAVEL, Nicolau. O príncipe. Trad. Antonio Caruccio-Caporale. São Paulo: L\&PM, 2013. 
Estabelece-se, resumidamente, uma meta, para onde se deve ir. Em nome da busca pela concretização dessa meta, admite-se, durante o percurso, qualquer tipo de articulação - os atalhos são bastante frequentes. A validade dos comportamentos estaria condicionada ao que se estabeleceu como objetivo principal.

O trajeto que se estabelece entre o fato e a pena não é dos mais simples. Não seria legítimo, em ambiente (pretensamente) democrático, utilizarmo-nos da conhecida máxima de algumas das ciências exatas, de que o caminho mais curto entre dois pontos é uma reta. Segundo a racionalidade jurídica moderna, os fins não justificam os meios, o que haverá de interessar é o caminho mais justo, razoável e equânime, com o maior respeito possível aos direitos humanos, com os quais uma democracia se compromete. Daí o motivo de não se pressuporem retas, numa investigação criminal. Na trajetória do jus persequendi, os obstáculos são frequentes e - poderíamos dizer - em certa medida, necessários.

Logo, os caminhos percorridos e os métodos utilizados no âmbito da instrução criminal são tão importantes quanto a necessidade de se fomentar o ideal de justiça. Nesse ambiente, que se pretende democrático, não haverá espaços para o vale-tudo. Respeitar limites é imprescindível. Obviamente que não é do que se convencionou chamar por impunidade que estamos a tratar. Em absoluto. Afirmamos, tão somente, que direitos e garantias fundamentais precisam ser respeitados, para que o poder de punir não seja exercido de forma arbitrária. É a existência e o respeito a essas limitações o que nos proporciona medir o grau de civilidade de um determinado sistema criminal. Temos, assim, historicamente erigida, uma importante barreira protegendo a autonomia das pessoas contra a interferência estatal indevida.

Nesse passo, é corrente, na doutrina e nos tribunais, a ideia de que ninguém deve ser obrigado a colaborar para com sua própria incriminação - permitindo-se, inclusive, o silêncio do investigado, sem que isto lhe possa pesar desfavoravelmente (veja-se, por exemplo, o Art. $5^{\circ}$, inciso LXIII, da Constituição da República, doravante CR). Ademais, para Joana Costa ${ }^{69}$, "o direito à não autoincriminação encontra-se intimamente

${ }^{69}$ COSTA, Joana. O princípio nemo tenetur na jurisprudência do Tribunal Europeu dos Direitos do Homem. Revista do Ministério Público, ano 32, n. ${ }^{\circ} 128$, 
relacionado com a presunção de inocência", ou seja, é aos agentes estatais a quem cabe o ônus da prova. Segundo Gustavo Badaró70, "é sempre lembrada a posição de Goldschmidt, segundo a qual os ônus são um imperativo do próprio interesse, que se manifestam sob a ameaça de um prejuízo”.

A ideia que se propaga a partir desse espaço comunicativo, moldado principalmente pela atual Constituição brasileira, é a de que se deve fomentar o desenvolvimento de uma estrutura acusatória no âmbito da investigação criminal. ${ }^{71}$ Assim, mantém-se a ideia de que um processo investigativo de viés democrático é feito com base no fair trial, o que deve ser fomentado entre todos os sujeitos processuais, observando-se os procedimentos previamente estabelecidos, atuando todos, sem exceção, nesse percurso, com o dever de lealdade, ética e, sobretudo, com boafé - o que, acaso inobservados, podem servir para desconstituir tanto as provas recolhidas quanto uma eventual condenação.

Nesse sentido, são inúmeros os elementos conceituais que, interligados, constituem-se como núcleo essencial do nemo tenetur se ipsum acusare. Há toda uma estrutura a sustentá-lo conceitualmente, tendo como objetivo albergar um núcleo intangível, sob pena de se ver sua razão de ser degenerar completamente. E mesmo as inflexões possíveis das camadas que envolvem o núcleo de um direito ou garantia fundamental, segundo se constata na jurisprudência do Tribunal Europeu de Direitos Humanos, não se devem dar no mero plano abstrato, "antes devendo ser verificada segundo as circunstâncias particulares do caso concreto, tomando em consideração o processo no seu conjunto"72.

No entanto, o que teriam essas questões de cunho essencialmente jurídico com a obra de Michel Foucault? Como vimos, sua vida é dedicada

outubro-dezembro, 2011, p. 118.

70 BADARÓ, Gustavo. O álibi do acusado e o in dubio pro reo no Acórdão da APN 470/MG. Revista dos Tribunais, vol. 933/2013, p. 251 - 272, Jul / 2013, DTR \2013\3799. Também: GOLDSCHMIDT, James. Teoría general del proceso. Barcelona: Labor, 1936. p. 82-83.

71 Para aprofundamento: PRADO, Geraldo. Sistema acusatório - a conformidade constitucional das leis processuais penais. 3.ed. Rio de Janeiro: Lumen Juris, 2005.

72 COSTA, Joana. O princípio nemo tenetur na jurisprudência do Tribunal Europeu dos Direitos do Homem. Revista do Ministério Público, ano 32, n. ${ }^{\circ} 128$, outubro-dezembro, 2011, p. 119. 
à escavação das relações de poder que existem na construção e na imposição desse sistema normativo de controle e de punição. Os capítulos 2 e 3 deixam um pouco dessa sua característica à mostra. Logo, isso nos auxilia a compreender e nos dá condições de atuar revelando e contrapondo as intenções escamoteadas nesse processo com a necessidade de se estabelecer e de fazer respeitar determinadas garantias, ainda que essa não seja uma proposta sua. Sabemos, portanto, que seu aparato teórico não foi moldado para garantir um tipo específico de processo penal.

Não obstante seu não-compromisso com um modelo específico de persecução, Michel Foucault permite-nos justificar ainda mais enfaticamente a necessidade de contenção do já naturalizado poder punitivo, constante em nossa história independentemente da existência do próprio sistema criminal. Nessas circunstâncias, as garantias estabelecidas normativamente se prestariam justamente a esse papel, o de estabeler

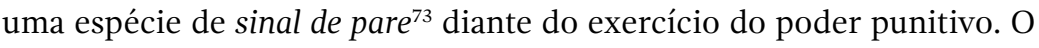
que se impõe, a partir daí, é uma racionalização que distancie vingança e justiça. Afinal, segundo François $\mathrm{Ost}^{74}$, “«dar tempo» é a condição para «exprimir o direito». E não será pelo facto do tempo ser dado que se (em)presta justiça?".

Ocorre que, o discurso essencialmente garantista, amparado constitucionalmente, não tem sido suficiente para evitar a realização de práticas abusivas, identificadas muito facilmente na dinâmica do sistema de justiça criminal, o que nos revela um problema de mentalidade. Exatamente nesse contexto, inserem-se as apresentações de pessoas presas, momento em que também se vê desconsiderado o direito de terem preservadas as suas imagens (art. $5^{\circ}$, inciso X, da CR), sobretudo quando são destinatários de uma medida cautelar. Por conta da mentalidade inquisitiva da qual é tributária a legislação processual penal brasileira, essas previsões constitucionais têm contrastado com as mencionadas práticas judiciárias no campo criminal ${ }^{75}$.

73 A expressão é de Ingo Wolfgang Sarlet, em: SARLET, Ingo Wolfgangt. Dignidade da pessoa humana e direitos fundamentais na Constituição Federal. 9. ed. Porto Alegre: Livraria do Advogado, 2012. p. 59.

74 OST, François. O tempo do Direito. Trad. Maria Fernanda Oliveira. Lisboa: Instituto Piaget, 2001. p. 434.

75 Sobre a matriz autoritária do processo penal brasileiro, para aprofundamento, recomenda-se: GLOECKNER, Ricardo Jacobsen. Autoritarismo e processo 
Apesar das contingências com as quais dialogava Michel Foucault, suas observações, por diversos motivos, conectam-se com a realidade brasileira. Seja por conta de ainda termos um Código de Processo Penal (Decreto-Lei n. 3.689, de 3 de outubro de 1941) cuja principal fonte de inspiração remete-nos à Europa vivenciada pelo autor, ${ }^{76}$ seja por seus constantes contatos com a comunidade acadêmica no Brasil, ou até mesmo pela atemporalidade das articulações que desvelou, o autor tem nos permitido compreender essa movimentação autoritária em terrae brasilis, reverberada acriticamente pelos veículos de comunicação ${ }^{77}$.

A partir de Foucault, seria preciso constatar que (a construção da) verdade e poder se entrelaçam, que ambos nutrem uma relação simbiótica. Nele, afirma-se que a verdade tem sido construída por meio de interações advindas do exercício de diversos poderes. Logo, cada sociedade possui seu regime de verdades, uma espécie de "política geral de verdade"78, ou seja, práticas e discursos que, por um lado, acolhem e fomentam, e, por outro, repelem e desestimulam, disseminando assim enunciados verdadeiros e falsos. O âmbito das práticas judiciárias no campo criminal, com as apresentações de pessoas presas e a busca pela confissão, como instrumentos sociais de controle, não poderia estar de fora desse contexto.

Partindo-se dessa perspectiva - que muito nos aproxima do instrumental foucaultiano, vez que uma de suas metas era mostrar que parte dos fenômenos que podem soar como familiares não decorrem de certas mudanças históricas muito precisas ${ }^{79}-$, convém destacar que as práticas

penal: uma genealogia das ideias autoritárias no processo penal brasileiro, v. 1. Florianópolis: Tirant lo blanch, 2018.

76 Veja-se a exposição de motivos do referido diploma. Disponível em: http:// honoriscausa.weebly.com/uploads/1/7/4/2/17427811/exmcpp_processo_ penal.pdf. Acesso em 3 dez. 2018. Sobre as influências de Rocco e Manzini na codificação brasileira do processo penal, ver: GLOECKNER, Ricardo Jacobsen. Op. Cit.

77 Conforme pode ser melhor observado em: GOMES, Marcus Alan de Melo. Mídia e sistema penal: as distorções da criminalização nos meios de comunicação. Rio de Janeiro: Revan, 2015.

78 FOUCAULT, Michel. Microfísica do poder. Rio de Janeiro: Paz e Terra, 2015. p. 52.

79 FOUCAULT, Michel. La inquietud por la verdad - escritos sobre la sexualidad y el sujeto. Buenos Aires: Siglo Veintiuno, 2015. p. 233. 
judiciárias no campo criminal têm sido útil a um Estado espetáculo. ${ }^{80} \mathrm{Ne}$ verdade, percebe-se que o sistema punitivo termina sendo legitimado, por meio da espetacularização e do sensacionalismo, que marcam as práticas midiáticas brasileiras ${ }^{81}$.

A apresentação de pessoas presas, como uma de suas modalidades mais usuais no funcionamento da segurança pública, não se constitui em um mero acaso. O sujeito (inimigo), uma vez preso (capturado), em nome do bem comum, é impelido a fazer parte de um procedimento (encenação) que serve para apresenta-lo (exibi-lo) à comunidade através da imprensa.

É com esse tipo de articulação (Estado/mídia/sociedade) muito conveniente que, ao invés de informações, reproduzem-se, na realidade, desinformações. A existência persistente desse cenário mitificado, no sentido trabalhado por Rubens Casara ${ }^{82}$, influencia diretamente "na ação dos atores jurídicos e nas decisões judiciais". Para o mencionado autor, "a mídia constrói a verdade, define o que se vai entender por justiça e confere o status do acusado em determinado caso penal, declara quem é vítima de erro judiciário, ou quem é culpado" ${ }^{83}$. Mantém-se, assim, “um círculo vicioso, com a fabricação coletiva de determinada representação social e o discurso surgido 'de cima para baixo' acaba sendo repetido 'de baixo para cima', tornando-se hegemônico"84.

Nesse contexto, a ideia de que a participação do investigado na persecução seria necessária às práticas criminais parece ter horrorizado Foucault. Tanto que um de seus mais conhecidos biógrafos, Didier Eribon ${ }^{85}$, refletindo sobre a busca pela confissão, conclui que "há indícios desse horror em todo o esforço realizado por seus últimos livros no sentido de

80 No sentido encontrado em: SCHWARTZENBERG, Roger-Gérard. O Estado espetáculo - ensaio sobre e contra o star system em política. Trad. Heloysa de Lima Dantas. São Paulo: Círculo de Livro, 1977.

81 BUDÓ, Marília. Mídia e controle social: da construção da criminalidade dos movimentos sociais à reprodução da violência estrutural. Rio de Janeiro: Revan, 2013, p. 109.

82 Sobre isso: CASARA, Rubens R. R. Mitologia processual penal. São Paulo: Saraiva, 2015.

83 CASARA, Rubens R. R. Op Cit. p. 245.

84 CASARA, Rubens R. R. Op Cit. p. 245.

85 ERIBON, Didier. Michel Foucault. São Paulo: Companhia das Letras, 1990. p. 44. 
rechaçar, recusar, resistir à imposição de dizer, de falar, de fazer falar". Tanto, que os últimos anos de Foucault foram voltados para a problemática do que ele chamou de veridição, já explorada no capítulo 3 - uma característica presente historicamente no processo penal brasileiro, o que, certamente, ajudou na consolidação da mal disfarçada arquitetura inquisitória de nosso sistema punitivo.

Não é à toa que essa busca pela verdade (por vezes dita real) ${ }^{86}$, pelo incontroverso, acabou ganhando contornos de ideia fixa ${ }^{87}$ junto a boa parte das autoridades que lidam mais diretamente com o conflito. Uma parcela considerável de juízes, promotores (ou procuradores), delegados e demais agentes das forças de segurança pública costumam apontar para um bem maior (coletivo) como ponto de legitimação de eventuais supressões de direitos e garantias fundamentais (individuais). Uma visão obviamente deturpada dos valores democráticos. A flexibilização daqueles limites, a possibilidade de negociá-los privilegiando, por exemplo, hipóteses acusatórias já formuladas antes mesmo de a investigação ter se aprofundado, não são iniciativas compatíveis com um ambiente que se pretende democrático.

Salah Kaled Hassan Jr. ${ }^{88}$ esquadrinha a dinâmica ora em curso: prisão/exibição/confissão, conforme destacado anteriormente. Para ele, “como arte dirigida à obtenção da confissão, o processo inquisitório necessita de tempo para manipular o acusado; expediente instrutório, essa custódia é um instrumento de ofício: em ambiente normal, o acusado não

86 Sobre o tema, para uma visão crítica e aprofundada: KHALED JR., Salah Hassan. A busca da verdade no processo penal: para além da ambição inquisitorial. São Paulo: Atlas, 2013.

87 "Deus te livre, leitor, de uma ideia fixa; antes um argueiro, antes uma trave no olho”. MACHADO DE ASSIS, Joaquim Maria. Memórias póstumas de Brás Cubas. Rio de Janeiro: Nova Aguilar, 1994. Essa fixação mórbida pode fazer com que as hipóteses elaboradas para a fundamentação da acusação prevaleçam sobre os fatos provados nos autos. CORDERO, Franco. Procedura penale, $9^{a}$ ed. Milão: Giuffrè, 2012, p. 25 e seguintes.

88 KHALED JÚNIOR, Salah Hassan. Precisamos resistir contra a expansão continuada do poder punitivo. Disponível em: http://www.conjur.com.br/2014dez-02/salah-khaled-preciso-resistir-expansao-poder-punitivo. Acesso em 15 abr. 2017. E mais: KHALED JÚNIOR, Salah Hassan; MORAIS DA ROSA, Alexandre. Neopenalismo e constrangimentos democráticos. Santa Catarina: Empório do Direito, 2015. 
confessaria”. É preciso que o investigado seja encorajado (eis a utilidade da prisão) a dizer algo útil, não necessariamente à resolução do conflito, mas à legitimação de toda a maquinaria estatal voltada contra si: "Diga que não erramos! Vamos, diga!”. Além disso, a confissão, por si, parece não bastar. Não raramente vemos as autoridades frequentando os telejornais com ar de frustração: "ao confessar, o sujeito não mostrou qualquer tipo de arrependimento".

A confissão é, portanto, funcional, serve como elemento retórico importante para a construção e reverberação das verdades úteis (de que ele é imprescindível, sempre necessário, incontornável, além de essencialmente infalível) ao sistema criminal ora vigente. Não à toa popularizouse a figura da colaboração premiada, que também se traduz em ritos de estabelecimento das pretendidas verdades. Sua importância é tamanha, nessa dinâmica da persecução penal brasileira contemporânea, que se autorizou o Ministério Público, dentre outras providências, a deixar de oferecer uma eventual denúncia (art. $4^{\circ}$, $\S 4^{\circ}$, da Lei n. 12.850/2013), mitigando-se a obrigatoriedade da propositura da ação penal pública.

\section{Considerações finals}

É certo que a quantidade de publicações de Michel Foucault sobretudo póstumas ${ }^{89}$ - dificulta a compreensão sistemática de toda sua obra. Por isso, as observações aqui inseridas refletem apenas algumas de nossas perspectivas sobre o que registrou o autor em determinados momentos de sua vida intelectual. Tentamos estabelecer um vínculo entre o instrumental que ele nos ofereceu e práticas judiciárias emblemáticas no

89 Os estudos póstumos constituem basicamente degravações de conferências e recompilações de escritos publicados de maneira avulsa por Foucault em diversos países, especialmente na França. Um material que, segundo Edgardo Castro, supera, em número de páginas, a soma de todas as que compõem seus livros. Não obstante tudo isso, é muito provável que, por conta de uma cláusula testamentária vedando a publicação de seus escritos após a sua morte, o material arquivado e ainda não publicado seja consideravelmente volumoso. FOUCAULT, Michel. El poder, una bestia magnífica - sobre el poder, la prisión y la vida. Buenos Aires: Siglo Veintiuno, 2014. p. 9-10. O problema se põe também em: ERIBON, Didier. Michel Foucault. São Paulo: Companhia das Letras, 1990. p. 303. 
campo criminal, abstraindo-se daí a necessidade de vermos respeitadas determinadas garantias individuais.

Não há aqui, portanto, sob nenhuma hipótese, a pretensão de apresentarmos conclusões do tipo definitivas sobre seu pensamento, mas sim de fomentar o debate sobre a problemática proposta a partir de algumas das críticas que estão expostas nas obras que nos servem de parâmetro durante o desenvolvimento do presente trabalho. Tanto em $A$ verdade e as formas jurídicas quanto em Obrar mal, decir la verdad encontramos chaves que nos permitem acessar as intenções autoritárias que as práticas enfocadas carregam consigo.

O papel que se tem historicamente atribuído ao investigado na persecução penal brasileira - como nos casos das apresentações de pessoas presas e na busca quase que desenfreada pela confissão, passando-se ainda pelas colaborações premiadas -, é, sem dúvidas, parte importante do processo de construção das verdades que interessam à manutenção do sistema de justiça criminal como o principal artífice do exercício do poder punitivo. Não é por acaso que práticas restaurativas, tributárias de raízes abolicionistas, encontram sérias resistências. ${ }^{90}$

Para um sistema que se anuncia (constitucionalmente) como acusatório, as práticas enfocadas destoam do que se espera de um ambiente democrático. Cientes de uma realidade que demonstra que o controle mais eficaz se dá pelo melhor uso da linguagem, em paralelo com a redução de complexidade na relações intersubjetivas linguísticas, a comunicação é cada vez mais simbólica e irrefletida por um consumismo quantitativo de dados (no menor tempo possível), o que habilmente será utilizado para ser mais impactante, selecionando-se e até segregando-se determinados grupos.

As garantias normatizadas, especialmente aquelas inseridas na Constituição da República, ou não são utilizadas com o mesmo entusiasmo com que são anunciadas ou acabam deturpadas, em nome de um valor maior. Oferece-se a confissão como mecanismo de redenção do sistema em marcha, apresenta-se o preso à imprensa como uma forma de prestação

90 Essa dinâmica pode ser observada com alguma propriedade em: ACHUTTI, Daniel. Justiça restaurativa e abolicionismo penal - contribuições para um novo modelo de administração de conflitos no Brasil. São Paulo: Saraiva, 2014. 
de contas à sociedade. Logo, agentes estatais superam direitos e garantias fundamentais como se fossem inconvenientes ao pleno exercício de seus trabalhos em prol da comunidade.

Esse caldo cultural precisa ser superado, o que requer uma viragem valorativa que demanda intensos esforços (discursivos e práticos), para os quais reputamos como valiosos os ensinamentos do autor francês. Para cumprir com essa difícil tarefa, a obra de Michel Foucault - sempre atenta à continuidade de determinadas práticas, ao exercício desembaraçado do poder punitivo, e à perenidade de determinados discursos e sistemas de verdades - continua sendo uma ferramenta de extrema utilidade. Permite-nos observar em detalhes as raízes dessa estrutura de pensamento disciplinário e organização hierarquizada. ${ }^{91}$

\section{REFERÊNCIAS}

ACHUTTI, Daniel. Justiça restaurativa e abolicionismo penal - contribuições para um novo modelo de administração de conflitos no Brasil. São Paulo: Saraiva, 2014.

BADARÓ, Gustavo. O álibi do acusado e o in dubio pro reo no Acórdão da APN 470/MG. Revista dos Tribunais, vol. 933, p. 251-272, Jul./2013.

BATISTA, Nilo. A lei como pai. Passagens, v. 2, n. 3. Rio de Janeiro, 2010, p. 20-38.

BENTHAM, Jeremy. O panóptico. Belo Horizonte: Autêntica, 2000.

BUDÓ, Marília. Mídia e controle social: da construção da criminalidade dos movimentos sociais à reprodução da violência estrutural. Rio de Janeiro: Revan, 2013.

CASARA, Rubens R. R. Mitologia processual penal. São Paulo: Saraiva, 2015.

CASTRO-GÓMEZ, Santiago; GROSFOGUE, Ramón. El giro decolonial - Reflexiones para una diversidad epistémica más allá del capitalismo global. Bogotá: Siglo del Hombre, 2007.

CORDERO, Franco. Procedura penale, 9ª ed. Milão: Giuffrè, 2012.

91 No sentido trabalhado em: CASTRO-GÓMEZ, Santiago. Decolonizar la universidad - La hybris del punto cero y el diálogo de saberes. CASTRO-GÓMEZ, Santiago; GROSFOGUE, Ramón. El giro decolonial - Reflexiones para una diversidad epistémica más allá del capitalismo global. Bogotá: Siglo del Hombre, 2007. p. 79 ss. 
COSTA, Joana. O princípio nemo tenetur na jurisprudência do Tribunal Europeu dos Direitos do Homem. Revista do Ministério Público, ano 32, n. ${ }^{\circ} 128$, outubrodezembro, 2011.

ERIBON, Didier. Michel Foucault. São Paulo: Companhia das Letras, 1990.

FOUCAULT, Michel. Dits et écrits. Vol. III. París: Gallimard, 1994.

FOUCAULT, Michel. A verdade e as formas jurídicas. Rio de Janeiro: NAU, 2002.

FOUCAULT, Michel. Vigiar e punir - história da violência nas prisões. Petrópolis: Vozes, 2005.

FOUCAULT, Michel. ¿Qué es usted, professor Foucault? - sobre la arqueología y su método. Trad. Horacio Pons. Buenos Aires: Siglo Veintiuno, 2014.

FOUCAULT, Michel. El poder, una bestia magnífica - sobre el poder, la prisión y la vida. Buenos Aires: Siglo Veintiuno, 2014.

FOUCAULT, Michel. Obrar mal, decir la verdade: la función de la confesión en la justicia. Buenos Aires: Siglo Veintiuno, 2014.

FOUCAULT, Michel. Microfísica do poder. Rio de Janeiro: Paz e Terra, 2015.

FOUCAULT, Michel. La inquietud por la verdad - escritos sobre la sexualidad y el sujeto. Buenos Aires: Siglo Veintiuno, 2015.

FOUCAULT, Michel. A sociedade punitiva. São Paulo: Martins Fontes, 2015.

FOUCAULT, Michel. O que é um autor? 9a . ed. Lisboa: Vega Passagens, 2015.

FOUCAULT, Michel. A arqueologia do saber. Lisboa: Almedina, 2016.

FREUD, Sigmund. Totem e tabu. Obras completas, v. 11. São Paulo: Companhia das letras, 2012.

GLOECKNER, Ricardo Jacobsen. Autoritarismo e processo penal: uma genealogia das ideias autoritárias no processo penal brasileiro, v. 1. Florianópolis: Tirant lo blanch, 2018.

GOLDSCHMIDT, James. Teoría general del proceso. Barcelona: Labor, 1936.

GOMES, Marcus Alan de Melo. Mídia e sistema penal: as distorções da criminalização nos meios de comunicação. Rio de Janeiro: Revan, 2015.

KHALED JÚNIOR, Salah Hassan; MORAIS DA ROSA, Alexandre. Neopenalismo e constrangimentos democráticos. Santa Catarina: Empório do Direito, 2015. 
KHALED JÚNIOR, Salah Hassan. A busca da verdade no processo penal: para além da ambição inquisitorial. São Paulo: Atlas, 2013.

KHALED JÚNIOR, Salah Hassan. Precisamos resistir contra a expansão continuada do poder punitivo. Disponível em: http://www.conjur.com.br/2014-dez-02/ salah-khaled-preciso-resistir-expansao-poder-punitivo. Acesso em 15 abr. 2017.

MACHADO, Roberto. Foucault, a ciência e o saber, $3^{\mathrm{a}} \mathrm{ed}$. Rio de Janeiro: Jorge Zahar, 2007.

MACHADO, Roberto. Impressões de Michel Foucault. São Paulo: N-1, 2017.

MACHADO DE ASSIS, Joaquim Maria. Memórias póstumas de Brás Cubas. Rio de Janeiro: Nova Aguilar, 1994.

MAQUIAVEL, Nicolau. O príncipe. Trad. Antonio Caruccio-Caporale. São Paulo: L\&PM, 2013.

OLIVEIRA, Luciano. Do nunca mais ao eterno retorno - uma reflexão sobre a tortura. São Paulo: Brasiliense, 2009.

OLIVEIRA, Luciano. Relendo Vigiar e Punir. Revista Olhares Plurais - revista eletrônica multidisciplinar, vol. 1, n. 4, 2016, p. 6-30.

OLIVEIRA, Luciano. O aquário e o samurai: uma leitura de Michel Foucault. Rio de Janeiro: Lumen Juris, 2017.

OST, François. O tempo do Direito. Trad. Maria Fernanda Oliveira. Lisboa: Instituto Piaget, 2001.

REVEL, Judith. Michel Foucault - conceitos essenciais. São Carlos: Claraluz, 2005.

REVEL, Judith. La pensée verticale: une éthique de la problématisation. GROS, F. (Org.). Foucault: le courage de la vérité. $2^{\mathrm{a}} \mathrm{ed}$. Paris: PUF, 2012.

SARLET, Ingo Wolfgang. Dignidade da pessoa humana e direitos fundamentais na Constituição Federal. 9. ed. Porto Alegre: Livraria do Advogado, 2012.

SCHWARTZENBERG, Roger-Gérard. O Estado espetáculo - ensaio sobre e contra o star system em política. Trad. Heloysa de Lima Dantas. São Paulo: Círculo de Livro, 1977.

SÓFOCLES. Édipo-Rei. São Paulo: Perspectiva, 2001.

VEYNE, Paul. Foucault - seu pensamento, sua pessoa, 2. ed. Rio de Janeiro: Civilização Brasileira, 2014. 


\section{Informações adicionais e declarações dos autores (integridade científica)}

Agradecimentos (acknowledgement): O presente trabalho é dedicado ao Professor Luciano Oliveira (UNICAP), que sempre incentivou um olhar crítico sobre a obra de Michel Foucault, e à Professora Mariana Valverde (Universidade de Toronto), que nos chamou a atenção para as questões criminológicas contidas em Obrar mal, decir la verdad, de Michel Foucault.

Declaração de conflito de interesses (conflict of interest declaration): os autores confirmam que não há conflitos de interesse na realização das pesquisas expostas e na redação deste artigo.

Declaração de autoria e especificação das contribuições (declaration of authorship): todas e somente as pessoas que atendem os requisitos de autoria deste artigo estão listadas como autores; todos os coautores se responsabilizam integralmente por este trabalho em sua totalidade.

- Bruno Cavalcante Leitão Santos: revisão bibliográfica, redação, revisão crítica com contribuições substanciais, aprovação da versão final.

- Francisco de Assis de França Júnior: projeto e esboço inicial, coleta e análise de dados, levantamento bibliográfico, revisão bibliográfica, redação, revisão crítica com contribuições substanciais, aprovação da versão final.

- Hugo Leonardo Rodrigues Santos: coleta e análise de dados, levantamento bibliográfico, revisão bibliográfica, redação, revisão crítica com contribuições substanciais, aprovação da versão final.

Declaração de ineditismo e originalidade (declaration of originality): os autores asseguram que o texto aqui publicado não foi divulgado anteriormente em outro meio e que futura republicação somente se realizará com a indicação expressa da referência 
desta publicação original; também atestam que não há plágio de terceiros ou autoplágio. Este texto é o resultado de reflexões iniciadas durante a realização de um minicurso, ministrado por Hugo Leonardo Rodrigues Santos, nos dias 20 e 27 de janeiro de 2017, em Maceió/AL. O evento foi organizado pelo Grupo de Estudos Biopolíticas e Processo Penal (UNIT), o Laboratório de Ciências Criminais do IBCCRIM-CESMAC e o Núcleo de Estudos e Políticas Penitenciárias (UFAL).

Dados do processo editorial

(http://www.ibraspp.com.br/revista/index.php/RBDPP/about/editorialPolicies)

- Recebido em: $11 / 12 / 2018$

- Controle preliminar e verificação de plágio: $15 / 12 / 2018$

- Avaliação 1:15/12/2018

- Avaliação 2: 28/12/2018

- Avaliação 3: 10/01/2019

- Decisão editorial preliminar: 08/02/2019

- Deslocamento ao V5N2 e aviso autores: 08/02/2019

- Retorno rodada de correções: 20/02/2019

- Decisão editorial final: 30/03/2019
Equipe editorial envolvida

- Editor-chefe: 1 (VGV)

- Editor-assistente: 1 (RDG)

- Revisores: 3 


\section{COMO CITAR ESTE ARTIGO:}

SANTOS, Bruno C. L.; FRANÇA JÚNIOR, Francisco A.; SANTOS, Hugo L. R. Práticas judiciárias no campo criminal e a construção das verdades na persecução penal: um debate a partir de Michel Foucault. Revista Brasileira de Direito Processual Penal, Porto Alegre, vol. 5, n. 2, p. 1041-1072, mai./jun. 2019. https://doi.org/10.22197/rbdpp.v5i2.199

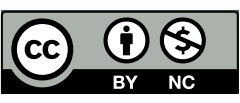

Esta obra está licenciada com uma Licença Creative Commons Atribuição-NãoComercial 4.0 Internacional. 